\title{
Pengaruh Pemberian Dadih dengan Perubahan Jumlah Lactobacillus fermentum Pada Feses Ibu Hamil
}

\author{
Ranne Balqis ${ }^{1}$, Andani Eka Putra², Bobby Indra Utama ${ }^{3}$, Helmizar $^{4}$
}

\begin{abstract}
Abstrak
Ibu hamil dengan asupan probiotik yang baik diketahui memiliki fungsi imun yang lebih baik dan kehamilan yang lebih sehat, menekan angka kejadian bayi prematur serta menurunkan prevalensi preeklamsi. Penelitian ini bertujuan untuk mengetahui pengaruh pemberian dadih terhadap jumlah L. fermentum pada feses ibu hamil. Penelitian ini dilakukan dengan desain equivalent pre-post test with control group. Populasi penelitian ini adalah ibu hamil dan sampel penelitian dipilih secara konsekutif. Setelah melakukan pengamatan pada awal penelitian pada kelompok perlakuan, ibu hamil diberikan $100 \mathrm{cc}$ dadih setiap harinya sampai akhirnya dilakukan pengamatan kedua. Rata-rata jumlah koloni pada ibu hamil sebelum mendapat dadih adalah $3,713 \log C F U / g\left(\log x=6 \times 10^{3}\right)$, sedangkan jumlah koloni rata-rata setelah mengonsumsi dadih adalah 4,580 $\log \mathrm{CFU} / \mathrm{g}\left(\log \mathrm{x}=46 \times 10^{3}\right)$. Hasil uji statistik didapatkan nilai $\mathrm{P}=0.367$. Sementara pada kelompok kontrol didapatkan bahwa rata-rata jumlah koloni pada ibu hamil yang tidak mengonsumsi dadih saat pengambilan sampel pertama (awal kehamilan) adalah 3,999 $\log \mathrm{CFU} / \mathrm{g}\left(\log \mathrm{x}=8 \times 10^{3}\right)$, sedangkan saat pengambilan sampel kedua (akhir kehamilan) rata-rata jumlah koloninya adalah 4,436 log CFU/g $\left(\log x=24 \times 10^{3}\right)$. Hasil uji statistik didapatkan nilai $P=0,475$. Perubahan jumlah koloni pada kelompok ibu hamil yang diberi dadih dan yang tidak diberi dadih diperoleh nilai P-value adalah 0,022 $(p<0,05)$. Tidak terdapat pengaruh signifikan pemberian dadih terhadap jumlah L. fermentum pada feses ibu hamil, namun ditemukan perubahan jumlah L. fermentum yang lebih banyak pada kelompok perlakuan.
\end{abstract}

Kata Kunci: dadih, probiotik, Lactobacillus fermentum, ibu hamil

\begin{abstract} was found better change after observation in intervention group.

Affiliasi penulis : 1. Program Studi Pasca Sarjana IImu Biomedik 2. Bagian Mikrobiologi FK Unand, 3. Bagian Obstetri dan Ginekologi FK Unand, 4. Universitas Andalas

Korespondensi : Jalan Perintis Kemerdekaan Padang

ranne.balqis14@yahoo.com Telp: 075136494
\end{abstract}

Pregnant women with adequate prebiotic consumption known having better immune function and also better pregnancy, depress the event of premature labor and pre-eclampsia event. This study conducted to find out the influence of dadih consumption to the change of the number of lactobacillus fermetum in pregnant women. This study was a experimental study with equivalent pre-post test with control group design. Population of this study was pregnant women, with sampling was done consecutively. Minimal total sample was 24 for each group. After observation at the beginning of study, intervention group was given 100cc dadih daily until second observation. Mean of colony in pregnant women before taking dadih was 3,713 CFU/mh and after was 4,580 log CFU/g ( $p=0.367)$. In control group, the number of colony at 1 st observation was 3,999 log CFU/g and 4,436 log CFU/g in 2 nd observation $(p=0.475)$. The changes in both groups were compared and resulting in significantly different change $(p=0.022)$. There is no statistically significant influence of dadih consumption with the change in the number of lactobacillus fermentum in pregnancy women. However, this study

Keywords: dadih, probiotic, Lactobacillus fermentum, pregnancy women

\section{PENDAHULUAN}

Bakteri asam laktat berpotensi memberikan dampak positif bagi kesehatan dan nutrisi manusia, beberapa di antaranya adalah meningkatkan nilai nutrisi makanan, mengontrol infeksi pada usus, meningkatkan pencernaan laktosa, mengendalikan beberapa tipe kanker, dan mengendalikan kadar kolesterol dalam darah. Sebagian keuntungan tersebut merupakan hasil dari pertumbuhan dan aksi bakteri selama pengolahan makanan, sedangkan sebagian lainnya hasil dari pertumbuhan beberapa BAL di dalam saluran usus saat mencerna makanan yang mengandung BAL sendiri. Bakteri asam laktat dapat menghambat pertumbuhan bakteri lain dengan memproduksi protein yang disebut bakteriosin. Salah satu contoh bakteriosin yang dikenal luas adalah nisin, diproduksi oleh Lactobacillus lactis ssp. Nisin dapat menghambat pertumbuhan beberapa bakteri, yaitu Bacillus, Clostridium, Staphylococcus, dan Listeria. Senyawa bakteriosin yang diproduksi BAL dapat bermanfaat karena menghambat bakteri patogen yang dapat merusak makanan ataupun membahayakan kesehatan manusia, sehingga keamanan makanan lebih terjamin. ${ }^{1}$

Ibu hamil yang memiliki asupan probiotik yang baik diketahui memiliki fungsi imun yang lebih baik, hal ini sesuai dengan pernyataan oleh Wibowo dkk (2015) yang menemukan bahwa konsumsi probiotik selama masa kehamilan merupakan prilaku yang aman bagi kesehatan. Lebih lanjut pada penelitian ini juga menemukan bahwa lbu dengan asupan probiotik teratur memiliki kehamilan yang lebih sehat, menekan angka kejadian bayi prematur dan juga dapat menurunkan prevalensi preeklamsi. Sedangkan penelitian yang dilakukan oleh Dottereud menemukan bahwa pemberian probiotik pada Ibu hamil dan balita 
dapat menekan angka kejadian dermatitis atopi, namun tidak berpengaruh pada sensitisasi alergen. ${ }^{2,3}$

Sementara dari beberapa penelitian diketahui bahwa dadih mengandung BAL yang potensial sebagai probiotik. Bakteri probiotik yang terkandung dalam dadih ini merupakan Lactobacillus dan Bifidobacterium. BAL dan produk turunannya mampu mencegah timbulnya berbagai penyakit. Merupakan makanan yang baik untuk menam $\neg$ bah stamina dan daya tahan tubuh, mencegah kanker usus, memperbaiki mikroflora intestinal, memperbaiki kembali kondisi usus setelah mendapat pengobatan antibiotik, mengobati diare yang disebabkan oleh antibiotik, virus dan bakteri, anti mutagen, anti karsinogenik dan efektif sebagai antivaginitis. 4,5

Oleh karena keberagaman penelitian yang di lakukan dan belum adanya identifikasi secara spesifik jumlah BAL pada feses Ibu hamil yang mengonsumsi dadih, maka dilakukan penelitian dengan judul "Pengaruh Pemberian Dadih dengan Perubahan Jumlah Lactobacillus fermentum pada Feses lbu Hamil".

Fermentasi asam laktat terbagi menjadi dua jenis, yaitu homofermentatif, sebagian besar hasil akhir merupakan asam laktat dan heterofermentatif, hasil akhir berupa asam laktat, asam asetat, etanol dan CO2. Secara garis besar, keduanya memiliki kesamaan dalam mekanisme pembentukan asam laktat, yaitu piruvat akan diubah menjadi laktat (atau asam laktat) dan diikuti dengan proses transfer elektron dari NADH menjadi NAD+. Pola fermentasi ini dapat dibedakan dengan mengetahui keberadaan enzim-enzim yang berperan di dalam jalur metabolisme glikolisis. ${ }^{6}$

Proses homofermentasi menyebabkan glukosa pada media terfermentasi menghasilkan asam laktat sebagai satu-satunya produk. BAL homofermentatif mampu menghasilkan enzim fruktosa difosfat aldolase. Metabolisme homofermentatif melibatkan aldolase dan heksosa aldolase namun tidak memiliki fosfoketolase serta hanya sedikit atau bahkan sama sekali tidak menghasilkan $\mathrm{CO} 2$. Jenis $\mathrm{BAL}$ homofermentatif antara lain adalah Streptococus, Pediococcus, dan beberapa Lactobacillus. ${ }^{7}$

Proses heterofermentatif menyebabkan glukosa pada media terfermentasi menghasilkan asam laktat dan senyawa-senyawa lainnya yaitu etanol, asam asetat dan $\mathrm{CO} 2$. Jenis BAL heterofermentatif antara lain adalah Leuconostoc, dan beberapa spesies Lactobacillus. BAL heterofermentatif tidak mampu menghasilkan enzim fruktosa difosfat aldolase, tetapi BAL heterofermentatif mampu menghasilkan glukosa 6 fosfat dehidrogenase dan 6 fosfat glukonat dehidrogenase sehingga mempunyai jalur pembentukan asam laktat yang berbeda. Pada heterofermentatif, tidak ada aldolase dan heksosa isomerase tetapi menggunakan enzim fosfoketolase dan menghasilkan CO2. Metabolisme heterofermentatif dengan menggunakan heksosa (golongan karbohidrat yang terdiri dari 6 atom karbon) akan melalui jalur heksosa monofosfat atau pentosa fosfat. ${ }^{8}$

\section{METODE}

Jenis penelitian ini adalah penelitian eksperimen semu (Quasi Eksperimen) dengan desain Equivalent pre-post test with control group design dimana dilakukan pengukuran terhadap subjek kelompok perlakuan dan kontrol sebelum dan sesudah perlakuan. Peneliti mengambil populasi ibu hamil di 10 Puskesmas di Dua Kecamatan (Baso dan Tilatang kamang), Kabupaten Agam, Sumatera Barat, karena sentra produksi dadih berada di salah satu Kecamatan ini dan dadih merupakan pangan yang tidak asing bagi masyarakat Agam dan sekitarnya.

Sampel pada penelitian ini dipilih secara konsekutif. Sampel pada kelompok perlakuan diberikan dadih selama kehamilan berlangsung, sedangkan kelompok kontrol tidak diberi dadih selama kehamilan. Kriteria inklusi:

a. Ibu hamil yang bersedia mengonsumsi dadih 100cc setiap hari (dadih akan diantar setiap harinya oleh petugas yang telah ditunjuk).

b. Ibu hamil yang tidak sedang mengonsumsi antibiotik.

c. Ibu hamil dalam kondisi baik atau tanpa kelainan.

d. Ibu hamil yang tidak mengkonsumsi probiotik lain.

Kriteria Eksklusi:

a. Ibu hamil yang alergi terhadap susu kerbau

b. Ibu hamil yang sedang mengalami diare

Jumlah sampel minimal pada setiap kelompok adalah 12 orang. Pemeriksaan BAL dilakukan di di Laboratorium Mikrobiologi Fakultas Kedokteran Universitas Andalas, dengan persamaan kurva standar ditetapkan sebesar $y=-1,8664 x+39,51$.

Kelompok perlakuan diberi dadih $100 \mathrm{cc} / \mathrm{hari}$ hingga akhir kehamilan, sedangkan kelompok kontrol tidak diberi dadih hingga akhir kehamilan. Lalu sampel berupa feses dikumpulkan pada akhir kehamilan dan dilakukan pemeriksaan. Dari sampel dilakukan isolasi DNA yang kemudian diproses menggunakan Real time PCR.

\section{HASIL}

Subjek yang ada di Wilayah kerja Puskesmas di Kecamatan Baso dan Tilatang Kamang, Kabupaten Agam adalah ibu hamil dengan karakteristik dasar responden secara umum adalah ibu hamil dengan usia rata-rata 31 tahun pada kelompok perlakuan, 28 tahun pada kelompok kontrol dengan usia kehamilan rata-rata 14 -15 Minggu, yang berjumlah 24 orang. Dari 24 orang tersebut 12 orang diberikan dadih selama masa kehamilan dan 12 orang lagi tidak diberikan dadih selama masa kehamilan. Selanjutnya dilakukan pemeriksaan terhadap sampel sebelum dan setelah perlakuan (Tabel 1).

Setelah uji normalitas data dilakukan dengan uji Kolmogorov-Smirnov, maka didapatkan bahwa jumlah koloni L. fermentum dalam feses terdistribusi normal (Nilai $P>0,05$ ). Selanjutnya untuk melihat pengaruh pemberian dadih dengan perubahan jumlah 
L. fermentum pada feses Ibu hamil digunakan uji TDependent (Parametrik).

Tabel 1. Karakteristik Responden

\begin{tabular}{ccc}
\hline $\begin{array}{c}\text { Karakteristik } \\
\text { Responden }\end{array}$ & Perlakuan & Kontrol \\
\hline $\begin{array}{c}\text { Usia ibu, tahun } \\
\text { (rerata } \pm S D)\end{array}$ & $31.25 \pm 5.72$ & $28.62 \pm 5.25$ \\
$\begin{array}{c}\text { Usia Kehamilan, } \\
\text { tahun (rerata } \pm S D)\end{array}$ & $14.23 \pm 1.88$ & $14.92 \pm 1.65$ \\
\hline
\end{tabular}

Pengaruh Pemberian Dadih dengan Perubahan Jumlah L. fermentum Terhadap Responden yang Mendapat Dadih (Perlakuan).

Penelitian ini dilakukan dengan mengambil sampel feses ibu hamil sebelum diberikan dadih, kemudian dilakukan pemeriksaan. Selanjutnya ibu hamil diberi $100 \mathrm{cc}$ dadih/Hari selama masa kehamilan dan pada akhir kehamilan sampel feses kembali diambil untuk diperiksa. Dari hasil penelitian menunjukkan bahwa rata-rata jumlah koloni pada ibu hamil sebelum mendapat dadih adalah $3.713 \log \mathrm{CFU} / \mathrm{g}(\log \mathrm{x}=$ $\left.6 \times 10^{3}\right)$, sedangkan jumlah koloni rata-rata setelah mengonsumsi dadih adalah $4.580 \log \mathrm{CFU} / \mathrm{g}(\log \mathrm{x}=$ $\left.46 \times 10^{3}\right)$. Hasil uji statistik didapatkan nilai $P=0.367$, secara statistik tidak terdapat pengaruh yang signifikan pemberian dadih dengan perubahan jumlah $L$. fermentum pada feses ibu hamil (Gambar 3 \& Tabel 2).

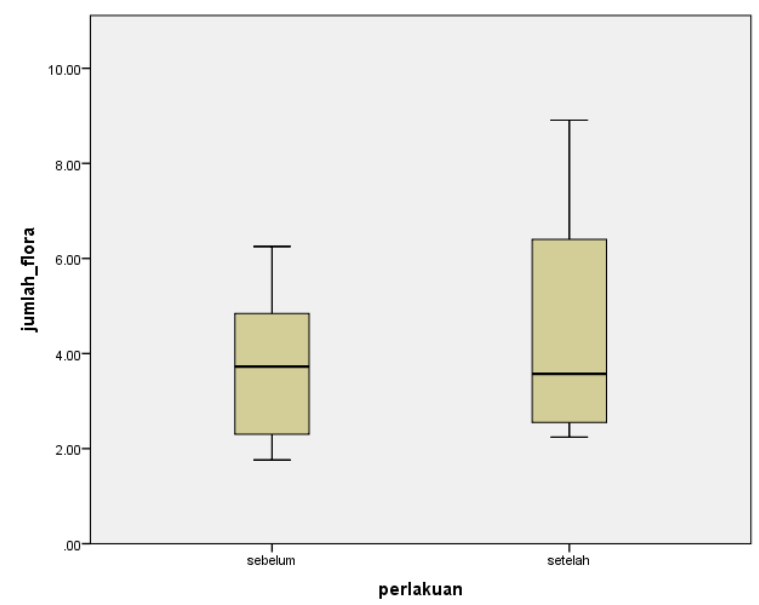

Gambar 3. Perubahan jumlah L. fermentum sebelum dan setelah mendapat dadih pada kelompok perlakuan

Tabel 2. Distribusi Rata-Rata Log Jumlah Koloni L. fermentum Terhadap Responden yang Mendapat Dadih (Perlakuan).

\begin{tabular}{cccc}
\hline Kelompok & $\begin{array}{c}\text { Sebelum } \\
\text { (log } \\
\text { CFU/g) }\end{array}$ & $\begin{array}{c}\text { Sesudah } \\
\text { (log } \\
\text { CFU/g) }\end{array}$ & p-value \\
\hline $\begin{array}{c}\text { Dadih } \\
\text { (perlakuan) }\end{array}$ & 3,713 & 4,580 & 0,367 \\
\hline
\end{tabular}

Pengaruh Pemberian Dadih dengan Perubahan Jumlah L. fermentum Terhadap Responden yang Tidak Mendapat Dadih (Kontrol).
Penelitian ini dilakukan dengan pengambilan sampel pertama (awal kehamilan), kemudian dilakukan pemeriksaan. Selanjutnya pengambilan sampel kedua dilakukan pada akhir kehamilan. Dari hasil penelitian didapatkan bahwa rata-rata jumlah koloni pada ibu hamil yang tidak mengonsumsi dadih saat pengambilan sampel pertama (awal kehamilan) adalah 3.999 log CFU/g $\left(\log x=8 \times 10^{3}\right)$, sedangkan saat pengambilan sampel kedua (akhir kehamilan) rata-rata jumlah koloninya adalah $4.436 \log \mathrm{CFU} / \mathrm{g}\left(\log \mathrm{x}=24 \times 10^{3}\right)$. Hasil uji statistik didapatkan nilai $P=0,475$, secara statistik tidak terdapat pengaruh yang signifikan terhadap perubahan jumlah L. fermentum pada feses ibu hamil sebelum dan setelah pengamatan (Gambar 4 \& Tabel 3).

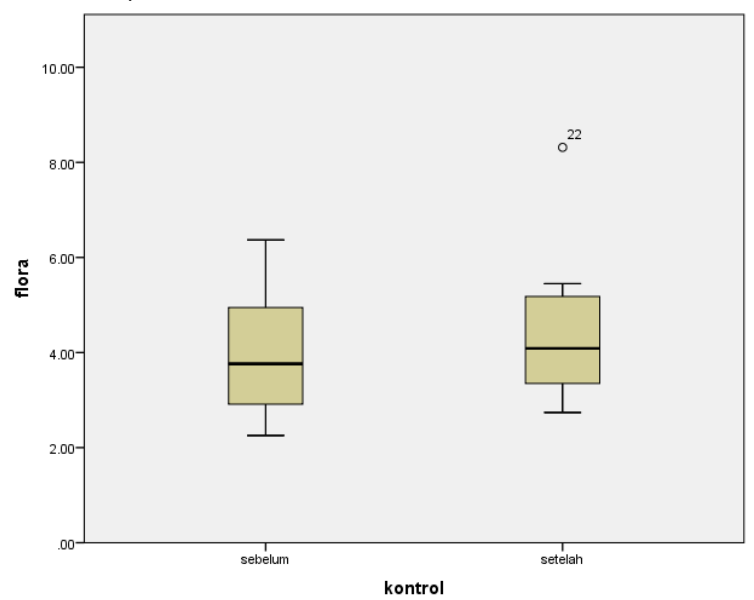

Gambar 4. Perubahan jumlah L. fermentum pada kelompok kontrol

Tabel 3. Distribusi Rata-Rata Log Jumlah Koloni L. fermentum Terhadap Responden Kontrol

\begin{tabular}{cccc}
\hline Kelompok & $\begin{array}{c}\text { Sebelum } \\
\text { (log } \\
\text { CFU/g) }\end{array}$ & $\begin{array}{c}\text { Sesudah } \\
\text { (log } \\
\text { CFU/g) }\end{array}$ & $\begin{array}{c}\text { p- } \\
\text { Value }\end{array}$ \\
\hline $\begin{array}{c}\text { Tidak dadih } \\
\text { (Kontrol) }\end{array}$ & 3.999 & 4.436 & 0,475 \\
\hline
\end{tabular}

Berdasarkan hasil penelitian diatas maka didapatkan hasil bahwa secara statistik tidak terdapat pengaruh yang signifikan terhadap perubahan jumlah $L$. fermentum pada feses ibu hamil pada kedua kelompok responden. Namun dijumpai peningkatan rerata jumlah L. fermentum yang lebih jelas pada kelompok perlakuan (Gambar 5)

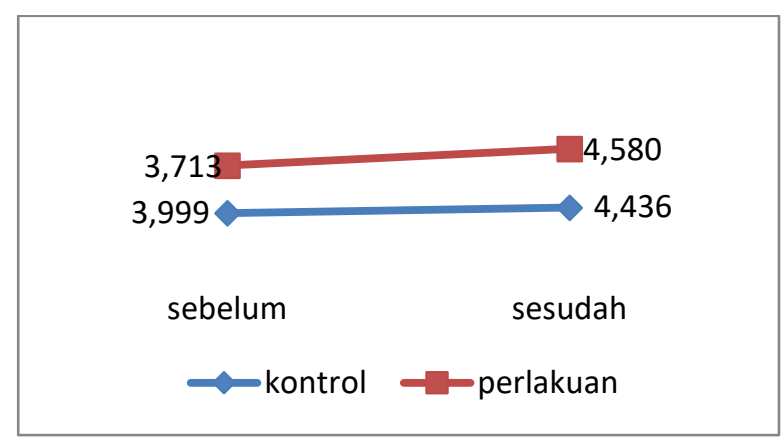


Gambar 5. Perubahan jumlah L. fermentum sebelum dan sesudah pada kelompok perlakuan dan kontrol

Dari hasil penelitian didapatkan perubahan bahwa ibu hamil yang diberi dadih dan yang tidak diberi dadih diperoleh nilai P-value adalah 0,022 $(p=<0.05)$. Dengan demikian didapatkan ada perubahan yang signifikan rata-rata jumlah $\mathrm{L}$. fermentum pada feses ibu hamil yang diberi dadih dan yang tidak diberi dadih. Dimana dijumpai peningkatan jumlah L. fermentum yang lebih bermakna pada kelompok perlakuan dari pada kelompok kontrol (Tabel 4).

Tabel 4. Perubahan Mikroflora Intestinal

\begin{tabular}{cccccc}
\hline Kelompok & $\mathbf{N}$ & $\begin{array}{c}\text { Mean } \\
\text { Pre } \\
(\text { Iog } \\
\text { CFU/g) }\end{array}$ & $\begin{array}{c}\text { Mean } \\
\text { Post } \\
\text { (log } \\
\text { CFU/g) }\end{array}$ & $\begin{array}{c}\text { Selisih } \\
\text { (log } \\
\text { CFU/g) }\end{array}$ & $\begin{array}{c}\text { p- } \\
\text { Value }\end{array}$ \\
\hline Perlakuan & 12 & 3,713 & 4,580 & 0,867 & \multirow{2}{*}{0,022} \\
Kontrol & 12 & 3,999 & 4,436 & 0,437 & \\
\hline
\end{tabular}

\section{PEMBAHASAN}

Pengaruh Pemberian Dadih dengan Perubahan Jumlah L. fermentum Pada Feses Ibu Hamil

Rata-rata jumlah L. fermentum pada kelompok perlakuan sebelum diberi dadih adalah 3,713 log CFU/g $\left(\log x=6 \times 10^{3}\right)$, setelah diberi dadih 4,580 log CFU/g $\left(\log x=46 \times 10^{3}\right)$ dan pada kelompok kontrol pada awal kehamilan adalah $\log 3,999 \mathrm{CFU} / \mathrm{g}\left(\log \mathrm{x}=8 \times 10^{3}\right)$ dan pada akhir kehamilan 4,436 $\log$ CFU/g $\left(\log x=24 \times 10^{3}\right)$. Artinya tidak terdapat pengaruh yang signifikan pemberian dadih terhadap jumlah L. fermentum pada feses ibu hamil. Hal ini tidak sejalan dengan penelitian yang dilakukan oleh Pundhir et al (2009) yaitu efek probiotik dalam lumen saluran cerna adalah meningkatkan mikroflora dengan menjaga keseimbangan mikroflora dan menjaga kolonisasi. ${ }^{9}$

Meskipun secara statistik tidak signifikan, hasil penelitian kami yang menunjukkan bahwa pemberian dadiah memperbesar jumlah L. fermentum pada feses ibu hamil, sejalan dengan penelitian Sekirov et al (2009) melakukan penelitian tentang kolonisasi bakteri gastrointenstinal menemukan bahwa infeksi yang terjadi akibat bakteri patogen dapat di tekan dengan konsumsi probiotik. Pada penelitian ini menemukan bahwa BAL yang terkandung pada makanan probiotik dapat meningkatkan aktifitas imun dengan mengeluarkan modulator biologis yang bersifat bakteriosid, meningkatkan aktifitas makrofag dan maturasi sel T dan B. ${ }^{10}$

\section{Probiotik Pada Ibu Hamil}

Probiotik merupakan organisme hidup yang dapat memberikan keuntungan terhadap kesehatan. Keuntungan kepada host apabila dikonsumsi sebagai food suplemen. Bakteri probiotik dapat digunakan sebagai pelengkap atau suplemen makanan alternatif. Bakteri probiotik yang banyak dikenal termasuk kelompok BAL dan termasuk mikroorganisme yang aman bagi kesehatan. Lactobacillus merupakan bakteri
Gram positif yang bersifat anaerob, berbentuk batang dan tidak bergerak dan paling banyak digunakan sebagai agen probiotik. Mikroflora saluran pencernaan merupakan bagian penting dalam dinding pertahanan usus. Komposisi awal dari mikroflora saluran pencernaan yang berkembang merupakan faktor penentu perkembangan fungsi pertahanan saluran pencernaan normal. Mikrobiota saluran pencernaan normal dapat mencegah pertumbuhan yang berlebihan dari bakteri patogen dalam saluran pencernaan. ${ }^{2,3}$

Bakteri probiotik memiliki banyak manfaat untuk kesehatan manusia, diantaranya dalam sistem imunitas dimana membantu daya tahan tubuh dan melindungi tubuh dari berbagai macam infeksi, sistem pencernaan yang baik dimana mampu mencegah masuknya bakteri pathogen dan memelihara integritas usus terhadap mikroorganisme. Dari beberapa penelitian diketahui bahwa dadih mengandung BAL yang potensial sebagai probiotik. Bakteri probiotik yang terkandung dalam dadih ini merupakan Lactobacillus dan Bifidobacterium. BAL dan produk turunannya mampu mencegah timbulnya berbagai penyakit. Merupakan makanan yang baik untuk menam $\neg$ bah stamina dan daya tahan tubuh, mencegah kanker usus, memperbaiki mikroflora intestinal, memperbaiki kembali kondisi usus setelah mendapat pengobatan antibiotik, mengobati diare yang disebabkan oleh antibiotik, virus dan bakteri, anti mutagen, anti karsinogenik dan efektif sebagai antivaginitis. ${ }^{4,5}$

Adapun beberapa faktor yang dapat memengaruhi jumlah kolonisasi flora normal dalam usus seperti: genetik, penyakit, penggunaan antibiotik, pola makan, berat badan dan kehamilan. BAL dikenal sebagai bakteri probiotik. Kadar BAL yang di temukan pada tubuh ibu baik pada kondisi normal ataupun pada masa kehamilan menunjukkan efek perbaikan metabolisme terutama dalam mengonversi gula menjadi bentuk lain seperti peningkatan asam laktat dalam pembentukan Air Susu Ibu (ASI). ${ }^{11,12}$

Ibu hamil yang memiliki asupan probiotik yang baik diketahui memiliki fungsi imun yang lebih baik, hal ini sesuai dengan penelitian sebelumnya yang menemukan bahwa konsumsi probiotik selama masa kehamilan merupakan prilaku yang aman bagi kesehatan. Lebih lanjut pada penelitian ini juga menemukan bahwa ibu dengan asupan probiotik teratur memiliki kehamilan yang lebih sehat, menekan angka kejadian bayi prematur dan juga dapat menurunkan prevalensi preeklamsi. Sedangkan penelitian yang dilakukan lain menemukan bahwa pemberian probiotik pada ibu hamil dan balita dapat menekan angka kejadian dermatitis atopi, namun tidak berpengaruh pada sensitisasi alergen. ${ }^{2,3}$

\section{SIMPULAN}

Dilihat dari hasil yang ditemukan pada penelitian ini, maka dapat diambil kesimpulan bahwa tidak terdapat pengaruh signifikan pemberian dadih terhadap jumlah L. fermentum pada feses ibu hamil dan ditemukan perubahan jumlah L. fermentum yang lebih 
banyak pada kelompok perlakuan. Untuk itu, diperlukan adanya penelitian lanjutan dengan luaran utamanya adalah penilaian secara objektif (klinis) mengenai manfaat pemberian dadih terhadap ibu hamil. Selain itu juga diperlukan penelitian lanjutan dengan sampel yang lebih banyak untuk dapat melihat efek pemberian dadih secara lebih luas.

\section{DAFTAR PUSTAKA}

1. Dugoua JJ, Machado M, Zhu X, Chen X, Koren G, Einarson TR. Probiotic Safety in Pregnancy: A Systematic Review and Meta-analysis of Randomized Controlled Trials of Lactobacillus, Bifidobacterium and Saccharomyces spp. Journal of Obstetry \& Gynaecology. 2009; 31(6):542-552.

2. Wibowo N, Mose JC, Karkata MK, Purwaka BT. Kristanto $\mathrm{H}$, Chalid MT, et al. The Status of Probiotics Supplementation during Pregnancy. Indonesian Medical Journal. 2015; 24;120-130.

3. Dottereud CK, Storre O, Johnsen R, Oien T. Probiotics in Pregnant Women to Prevent Allergic Disease: A Randomized, Double Blinded Trial. British Journal of Dermatology. 2010; 163:616-623.

4. Taufik E. Dadih Susu Sapi Hasil Fermentasi Berbagai Starter Bakteri Probiotik yang disimpan Pada Suhu Rendah: Karakteristik Kimiawi Media Perternakan. 2004; 27(3):88-100.

5. Afriani. Pengaruh Penggunaan Starter Bakteri Asam Laktat Lactobacillus plantarum dan Lactobacillus fermentum terhadapTotal Bakteri Asam Laktat, Kadar Asam dan Nilai pH Dadih Susu Sapi. Jurnal IImiah IImu-IImu Peternakan. 2009; 8(6):279-285.

6. Coelho LF, De Lima CJB, Rodovalho CM, Bernardo MP, Contiero Journal of Lactic Acid Production by New Lactobacillus Plantarum Lmism6 Grown in Molasses: Optimization of Medium Composition. Brazilian Journal of Chemical Engineering. 2011; 28(1):27-36.

7. Narayanan N, Roychoudhury PK, Srivastava A. L. Lactic Acid Fermentation and Its Product Polymerization. Journal of Biotechnology. 2004; 7(2):221-226.

8. Widyastuti $\mathrm{Y}$, Rohmatussolihat, Febrisiantosa A. The Role of Lactic Acid Bacteria in Milk Fermentation. Journal of Food and Nutrition Sciences. 2014; 5:435-442.

9. Pundir RK, Rana S, Kashyap N, Kaur A. Probiotic Potential of Lactic Acid Bacteria Isolated from Food Samples: An In Vitro Study. Journal of Applied Pharmaceutical Science. 2013; 3(3):085-093.

10. Sekirov I, Finlay BB. The Role of The Intestinal Microbiota in Enteric Infection. Journal of Physiology. 2009; 587(17):4159-4167.

11. Taylor BL, Woodfall GE, Sheedy KE, O'Riley ML, Rainbow KA, Bramwell EL, et al. Effect of Probiotics on Metabolic Outcomes in Pregnant Women with Gestational Diabetes: A Systematic Review and Meta-Analysis of Randomized Controlled Trials. Nutrients. 2017; 9:461.
12. Yavuzdurmaz H. Isolation, Characterization, Determination of Probiotic Properties of Lactic Acid Bacteria from Human Milk. [Tesis]. Izmir: Izmir Institute of Technology; 2007. 